\title{
The presence of primary cilia in cancer cells does not predict responsiveness to modulation of smoothened activity
}

\author{
ASHLEY L. SPANN, KUN YUAN, KAYLA F. GOLIWAS, ADAM D. STEG, \\ DEVANSHU D. KAUSHIK, YEON-JIN KWON and ANDRA R. FROST
}

Department of Pathology, University of Alabama at Birmingham, Birmingham, AL 35294, USA

Received March 9, 2015; Accepted April 14, 2015

DOI: 10.3892/ijo.2015.3006

\begin{abstract}
Primary cilia are microtubule-based organelles that regulate smoothened-dependent activation of the GLI transcription factors in canonical hedgehog signaling. In many cancers, primary cilia are markedly decreased or absent. The lack of primary cilia may inhibit or alter canonical hedgehog signaling and, thereby, interfere in the cellular responsiveness to modulators of smoothened activity. Clinical trials of smoothened antagonists for cancer treatment have shown the best response in basal cell carcinomas, with limited response in other solid tumors. To determine whether the presence or absence of primary cilia in cancer cells will predict their responsiveness to modulation of smoothened activity, we compared the ability of an agonist and/or inhibitor of smoothened (SAG and SANT1, respectively) to modulate GLI-mediated transcription, as measured by GLI1 mRNA level or GLI-luciferase reporter activity, in non-cancer cells with primary cilia (ovarian surface epithelial cells and breast fibroblasts), in cancer cells that cannot assemble primary cilia (MCF7, MDA-MB-231 cell lines), and in cancer cells with primary cilia (SKOV3, PANC1 cell lines). As expected, SAG and SANT1 resulted in appropriate modulation of GLI transcriptional activity in ciliated non-cancer cells, and failed to modulate GLI transcriptional activity in cancer cells without primary cilia. However, there was also no modulation of GLI transcriptional activity in either ciliated cancer cell line. SAG treatment of SKOV3 induced localization of smoothened to primary cilia, as assessed by immunofluorescence, even though there was no increase in GLI transcriptional activity, suggesting a defect in activation of SMO in the primary cilia or in steps later in the hedgehog pathway. In contrast to SKOV3, SAG treatment of PANC1 did not cause the localization of smoothened to primary cilia. Our data demonstrate that the
\end{abstract}

Correspondence to: Dr Andra R. Frost, Department of Pathology, University of Alabama at Birmingham, Birmingham, WTI 320B, 1720 2nd Avenue South, Birmingham, AL 35294, USA

E-mail: afrost@uab.edu

Key words: primary cilia, cancer, smoothened, inhibitors, agonists, hedgehog pathway presence of primary cilia in the cancer epithelial cells lines tested does not indicate their responsiveness to smoothened activation or inhibition.

\section{Introduction}

Activation of hedgehog signaling is implicated in the development and progression of a variety of cancers $(1,2)$. In canonical hedgehog signaling, hedgehog ligand activates hedgehog signaling by binding to the transmembrane receptor patched 1 (PTCH1). This binding relieves the inhibition by PTCH1 of the transmembrane, G-protein coupled receptor smoothened (SMO), via an unknown mechanism (3). Activation of SMO initiates a sequence of events that leads to the translocation of the activated GLI transcription factors to the nucleus and the initiation of GLI-mediated transcription (GLI-MT) (1). The vertebrate GLI family of zinc-finger transcription factors coordinately regulate GLI-MT and includes GLI1, GLI2 and GLI3 (4). GLI1 is exclusively a transcriptional activator and functions as the terminal activator and amplifier of GLI-MT (5). GLI2 and GLI3 have activator and repressor forms. GLI2 is predominantly a transcriptional activator and is involved in the initiation of GLI-MT, and GLI3 is primarily a transcriptional repressor (5-7). Transmission of the hedgehog signal is also regulated by the primary cilium (PC), a solitary, microtubulebased organelle that projects from surfaces of most cell types (8). Many hedgehog pathway members, including SMO, and the GLI transcription factors, localize to the PC upon pathway activation and, conversely, PTCH1 exits the PC. Accumulation of GLI2 and GLI3 in the ciliary tip results in their activation, translocation to the nucleus and initiation of GLI-MT. The role of primary cilia (PC) in the activation of GLI1 is less clear (8-10). Although the GLI transcription factors were first identified through their roles as mediators of hedgehog signaling, GLI-MT is also activated and modulated by other signaling pathways, including TGF $\beta$, ras/ERK, wnt, and myc (11-15).

Constitutive activation of hedgehog signaling by mutations of pathway members drives tumorigenesis of basal cell carcinomas, medulloblastomas, and rhabdomyosarcomas (16). In other cancers, mutations of hedgehog pathway members are rare $(1,16)$. However, GLI-MT is frequently upregulated in these cancers and has been implicated in the development or progression of many different tumor types $(5,10,17)$. As a consequence, multiple small molecule inhibitors of the hedgehog pathway 
that interfere in the activity of SMO have been developed. Eight of these are currently in clinical trials for the treatment of basal cell carcinomas, solid tumors and leukemias (2). Early clinical trial results have shown variable response to SMO antagonism among cancers of different types and even among cancers of the same type $(2,18,19)$. The underlying cause of this differential response remains largely unknown.

Given the central role of PC in transmission of the hedgehog signal, we and others (20-22) postulate that the presence of PC in cancer cells might indicate active canonical hedgehog signaling and predict an appropriate response to modulation of SMO activity. Conversely, the absence of PC in cancer cells might indicate inactive or aberrant canonical hedgehog signaling and a lack of responsiveness of these cells to SMO agonists or antagonists. If true, the presence or absence of PC in cancer cells could explain the variable response of different cancers to SMO antagonists. In addition, the presence of PC on cancer epithelial cells could also be used as a biomarker of clinical response to SMO antagonists. To test whether the absence or presence of PC correlates with responsiveness to modulation of SMO activity, we compared GLI transcriptional activity in response to a SMO agonist and antagonist in cancer cells that do and do not assemble PC, and in non-cancer cells that readily assemble PC.

\section{Materials and methods}

Cell lines. MCF7 cells were obtained from the American Type Cell Culture Collection (Manassas, VA, USA) in 2001. MDA-MB-231 (231) were a gift of Dr Danny Welch (University of Kansas) in 2006; SKOV3ip1 (SKOV3) were a gift of Dr Charles Landen (University of Alabama at Birmingham) in 2011; IOSE-Van (IOSE) were a gift of Dr William Grizzle (University of Alabama at Birmingham) in 2011. PANC1 cells were a gift of Dr Martin Johnson (University of Alabama at Birmingham) in 2006. The NAF were isolated by us from benign human breast tissues in 2001 (23). MDA-MB-231, IOSE, SKOV3, PANC1 and NAF were maintained in DMEM (Cellgro) supplemented with 10\% fetal bovine serum (FBS) (Hyclone, GE Life Sciences, Logan, UT, USA). MCF7 were maintained in DMEM supplemented with 10\% FBS and $0.01 \mathrm{mg} / \mathrm{ml}$ insulin. In some experiments, cells were transfected with the GLI1 expression vector pcDNA3.1-HA-Gli1, a gift of Dr Michael Ruppert (University of West Virginia). All the cell lines were maintained in $5 \% \mathrm{CO}_{2}$ at $37^{\circ} \mathrm{C}$ under humidified culture conditions. The identities of 231, MCF7, SKOV3 and PANC1 cell lines were confirmed by STR analysis (DNA profiling performed in the University of Alabama at Birmingham Heflin Genomics Core Laboratory) on 9/2014 (PANC1), 7/2014 (MCF7 and SKOV3), and 8/2010 (231).

Treatment with SMO agonists and antagonists. The SMO agonist SAG (CAS 364590-63-6; Santa Cruz Biotechnology, Dallas, TX, USA) and the SMO antagonist SANT1 (CAS 304909-07-7; Sigma-Aldrich, St. Louis, MO, USA) were dissolved in sterile water. The SMO antagonist cyclopamine (CAS 4449-51-8; Toronto Research Chemicals, Toronto, Ontario, Canada) was dissolved in DMSO. Cells $\left(5 \times 10^{5}\right)$ were seeded into 6-well plates and subsequently treated with SMO agonist or antagonist or the appropriate vehicle control upon reaching $90-95 \%$ confluence for the indicated times at the indicated concentrations in low serum conditions (respective culture media supplemented with $0.5 \%$ FBS) either with or without prior serum starvation for $48 \mathrm{~h}$ to allow formation of PC.

Quantitative PCR (RT-qPCR). RNA was pretreated with DNase and extracted (illustra RNAspin Mini kit, GE Life Sciences) as per the manufacturer's protocol. cDNA synthesis was carried out using the High Capacity cDNA Reverse Transcription kit (Life Technologies, Grand Island, NY, USA) according to the manufacturer's protocol. TaqMan ${ }^{\circledR}$ Gene Expression Assay primer and probe sets (Life Technologies) were used for real-time, quantitative PCR (RT-qPCR) analysis of GLI1 (assay ID=Hs00171790_m1) and ribosomal protein, large, P0 (RPLPO; assay ID=Hs99999902_m1) as the endogenous control (24). Samples were prepared in triplicate utilizing JumpStart Taq ReadyMix for High Throughput Quantitative PCR (Sigma-Aldrich). The log-linear phase of amplification was monitored to obtain $\mathrm{Ct}$ (threshold cycle) values utilizing the Roche LightCycler480 Real-Time PCR machine or the Applied Biosystems Step One Real-Time PCR system. The comparative $\mathrm{Ct}$ method was employed to determine relative expression levels.

Transfection and luciferase assay. The pGL3B/8xGliBS-lc-luc vector (Johns Hopkins Special Collection; American Type Culture Collection) and the renilla endogenous control vector pRL-TK (Promega, Madison, WI, USA) were cotransfected at a ratio of 50:1 using Lipofectamine 2000 (Life Technologies). Control cultures were transfected with either the negative control vector pGL3-Basic (Promega) or the positive control vector pcDNA3.1-HA-Gli1. Cells were subsequently treated in low serum conditions for $30 \mathrm{~h}$ at the indicated times after transfection. Upon completion of treatment, the luciferase assay was performed via the Dual-Luciferase Reporter Assay protocol (Promega) according to the manufacturer's protocol. Firefly luciferase results were normalized to endogenous renilla luciferase activity.

MTT assay. Cell viability with and without SANT1 treatment was assessed by MTT assay (CellTiter 96 Aqueous One Solution; Promega), as per the manufacturer's protocol. Cells $\left(6 \times 10^{3}\right)$ were plated per well in $100 \mu \mathrm{l}$ of appropriate media in a 96-well plate and were allowed to adhere for $24 \mathrm{~h}$. Cells were treated with the indicated concentrations of SANT1 for the indicated time period prior to assay.

Immunofluorescence for PC and SMO. Cells $\left(5 \times 10^{5}\right)$ were seeded onto cover slips and cultured for the indicated time periods in low serum $(0.5 \%$ FBS $)$ conditions after $48-\mathrm{h}$ serum starvation. Cells were washed with PBS, fixed in $3.7 \%$ paraformaldehyde for $10 \mathrm{~min}$ and incubated in blocking solution [2\% horse serum, $0.1 \%$ Triton X-100 in phosphatebuffered saline (PBS)] for $30 \mathrm{~min}$. Cells were then incubated in primary antibodies to acetylated $\alpha$-tubulin (mouse monoclonal, 1:500 dilution; Sigma-Aldrich) alone or with primary antibody to SMO (rabbit polyclonal, 1:100 dilution; Santa Cruz Biotechnology) for one hour at room temperature. After washing with PBS, cells were incubated with secondary anti- 
body (donkey anti-mouse Alexa 594 and donkey anti-rabbit Alexa 488; Life Technologies) at 1:500 dilution for one hour at room temperature, followed by washing with PBS and incubation with 4',6-diamidino-2-phenylindole (DAPI, $5 \mathrm{mg} / \mathrm{ml}$; Sigma-Aldrich) at 1:200 dilution in PBS. Slides were mounted with Fluoromount-G (Southern Biotech, Birmingham, AL, USA). Cells in a minimum of 10 high power fields were counted for PC and a minimum of 100 PC were assessed for the localization of SMO per condition.

Statistical analysis. Expression of GLI1 mRNA, GLI-luciferase activity, cell viability, and frequency of PC were compared by one-way ANOVA with Dunnett's multiple comparison test or Mann-Whitney test, as appropriate utilizing GraphPad Prism, version 6.01 (GraphPad software, La Jolla, CA, USA).

\section{Results}

There is not a direct correlation between the presence of $P C$ and GLII $\mathrm{mRNA}$, an indicator of GLI transcriptional activity. Most cell types in normal tissues are capable of assembling PC (25). Culture of fibroblasts and some types of epithelial cells derived from normal tissues in growth arrested conditions has shown a high incidence of PC (60-80\% of cells with PC) $(26,27)$. In cancers, there is considerable variability in the degree of PC formation. We and others have previously shown that most breast cancer epithelial cells and breast cancer cell lines do not assemble PC and when they do, the incidence is low ( $<4 \%$ of cells with PC) $(26,28,29)$. However, several ovarian cancer cell lines have been reported to exhibit a higher incidence, with $\sim 20 \%$ of cells having PC (27). To compare the ability of SMO activity to regulate GLI-MT in ciliated and non-ciliated cancer cells, we utilized MCF7 and MDA-MB-231 (231) breast cancer cell lines to represent non-ciliated cancer cells and the SKOV3ip1 (SKOV3) ovarian cancer cell line to represent ciliated cancer cells. Non-cancer cell lines that are capable of forming PC, specifically fibroblasts derived from normal breast (NAF) (23) and an immortalized ovarian surface epithelial cell line isolated from normal ovary, IOSE-Van (IOSE) (30), were expected to respond to modulation of SMO with appropriate changes in GLI-MT and were used as control cells. To confirm the level of PC formation in these different cell lines, the incidence of PC in serum starved cells was determined by immunofluorescence (IF) with antibodies directed to acetylated $\alpha$-tubulin (Fig. 1A) to mark PC. To attempt to maximize PC assembly, cells were grown to confluence and serum starved for $48-72 \mathrm{~h}$ prior to IF. NAF exhibited a high incidence of cells with PC (67\%) (Fig. 1B). The IOSE and SKOV3 cells demonstrated a lower percentage of cells with PC; whereas, the breast cancer cell lines showed no PC. Since PC are known to be important for the regulated transmission of the hedgehog signal $(8,31)$, we measured the mRNA expression of GLI1 in these cells cultured similarly to the conditions for PC incidence. GLI1 is a consistent transcriptional target of hedgehog signaling and GLI-MT $(7,32)$ and its mRNA expression is used as a readout of GLI transcriptional activity. In general, the ciliated cell lines had a higher level of GLI1 expression than the non-ciliated cell lines, but there was not a direct correlation between GLI1 and the percentage of cells with PC $(r=0.872$,
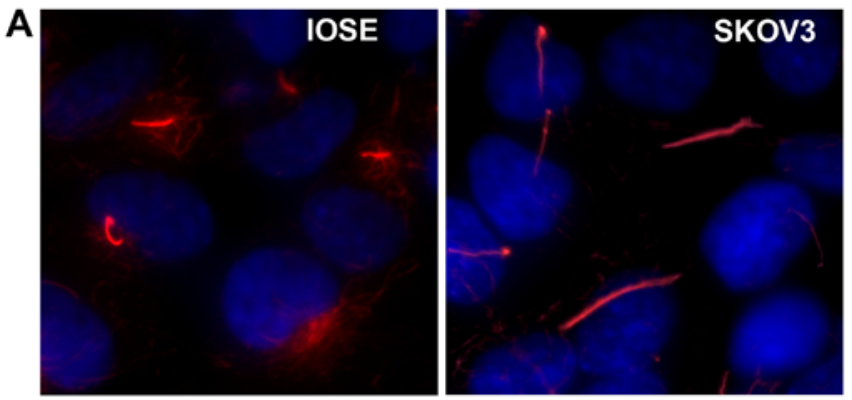

B

Incidence of PC

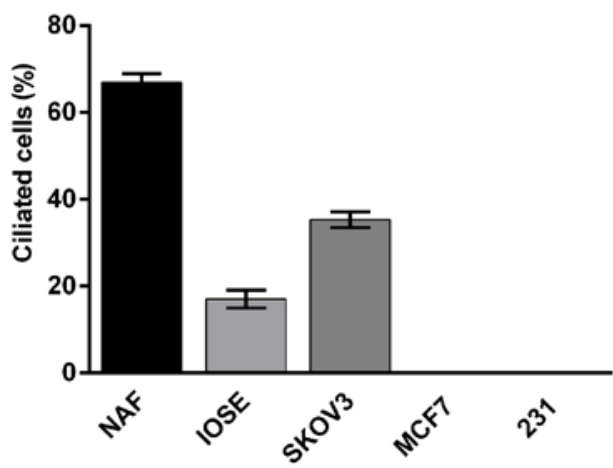

C

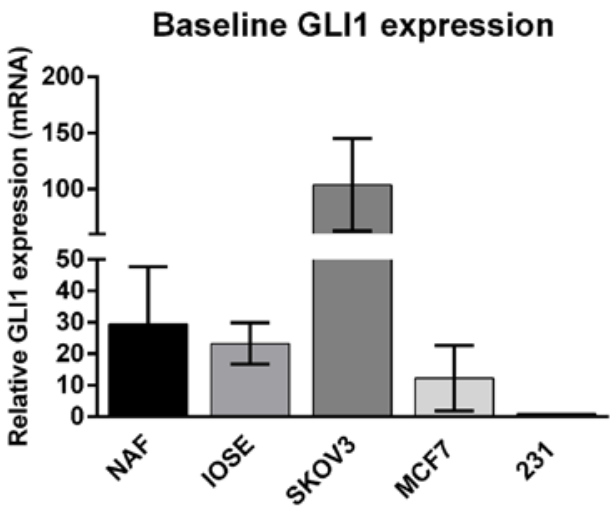

Figure 1. GLI1 expression does not require the presence of PC. (A) PC were identified by immunofluorescence for acetylated $\alpha$-tubulin (red), a marker for the ciliary axoneme, after $48 \mathrm{~h}$ of serum starvation. Nuclei were stained with DAPI (blue). PC in SKOV3 and IOSE are depicted. (B) The percentage of cells with PC was counted in a minimum of 10 high power fields. Breast cancer cell lines (MCF7, 231) demonstrated no PC, whereas the incidence of PC was intermediate in the ovarian cell lines and highest in the NAF. (C) Despite having fewer ciliated cells compared to the NAF, SKOV3 exhibited the highest level of GLI1 expression, as measured by quantitative RT-qPCR. Conversely, NAF had comparable GLI1 expression to that of the less ciliated IOSE. Data are the mean and standard error of 2 independent experiments performed in growth conditions identical to (A) and (B).

$\mathrm{p}=0.1$, Spearman correlation) (Fig. 1C). GLI1 was highest in SKOV3 cells, not NAF which had the highest percentage of ciliated cells; and MCF7 and 231 cells express GLI1 even in the absence of PC. This indicates that PC are not required for GLI1 expression, which might be explained by prior research showing the GLI-MT and GLI1 are upregulated by a number of signaling pathways other than hedgehog (11-15).

Modulation of SMO activity in non-cancer ciliated cells affects canonical hedgehog signaling and GLI-mediated transcription. To confirm the ability of non-cancer ciliated cells to 

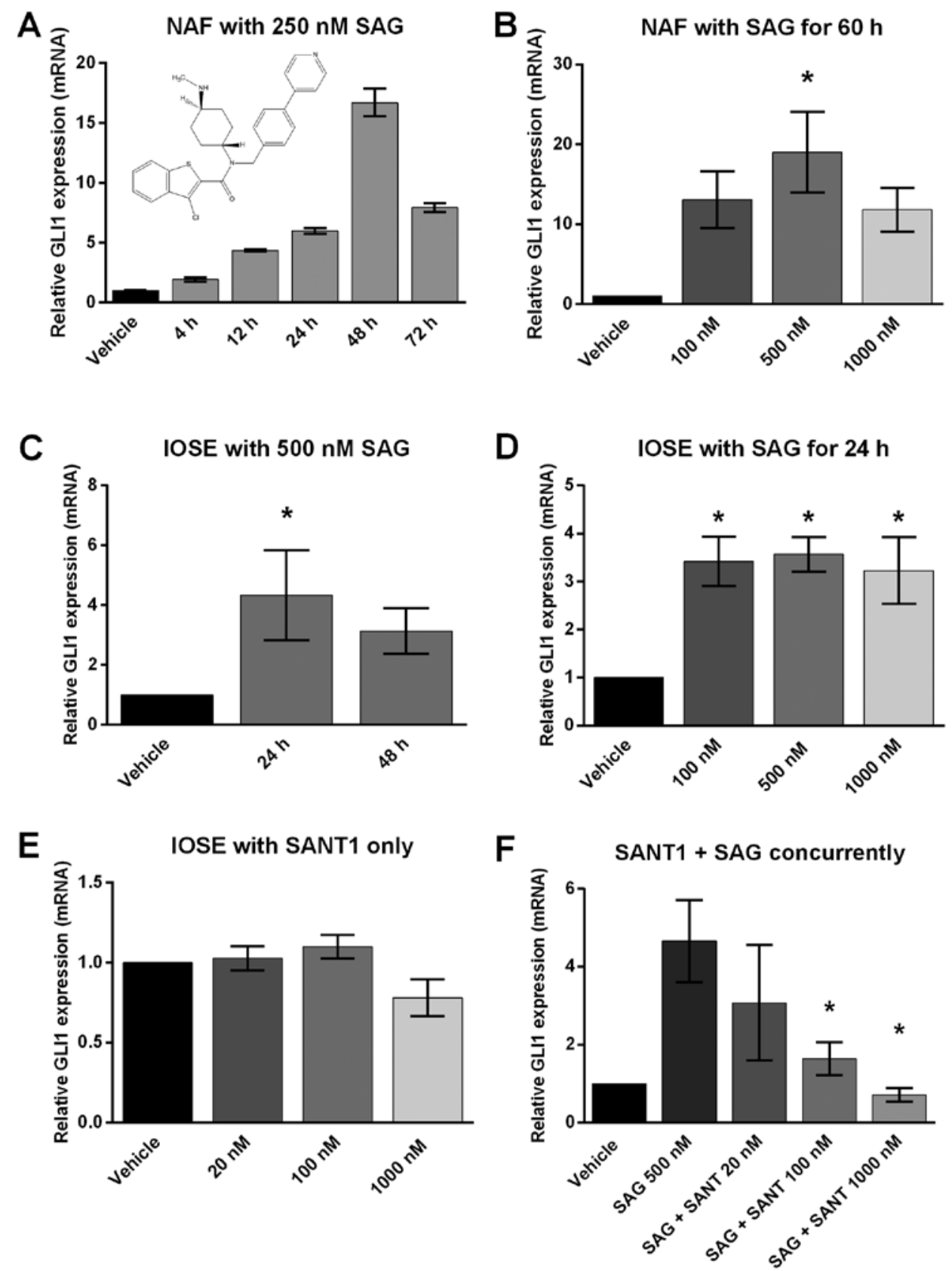

Figure 2. Non-cancer ciliated cells respond appropriately to SMO activation and inhibition. (A-D) GLI1 mRNA, as measured by QRT, is increased through activation of SMO by SAG in ciliated NAF and IOSE. Cells were serum starved for $48 \mathrm{~h}$ prior to SAG treatment. (A) A time course in NAF with $250 \mathrm{nM}$ SAG demonstrated the greatest expression at $48 \mathrm{~h}$ (17-fold) and $72 \mathrm{~h}$ (8-fold). Data are the mean and standard deviation of 3 assay replicates. The chemical structure of SAG is provided. (B) Dose response in NAF at 60-h treatment with SAG showed a significant 19 -fold increase in GLI1 expression at $500 \mathrm{nM}$ (p<0.01, ANOVA). Data are the mean and standard error of 6 experimental replicates.(C) Treatment of IOSE with $500 \mathrm{nM}$ SAG resulted in a significant 4-fold increase in GLI1 at $24 \mathrm{~h}$ ( $\mathrm{p}=0.02$, ANOVA). (D) A dose response at $24 \mathrm{~h}$ showed a significant increase in GLI1 at all concentrations ( $<<0.001$, ANOVA) in IOSE. (C and D) Data are the mean and standard error of 3 experimental replicates. (E and F) IOSE respond to SANT1 with a decrease in GLI1 expression after SAG treatment. Cells were serum starved for $48 \mathrm{~h}$ prior to SANT1/SAG treatment. (E) SANT1 alone for $48 \mathrm{~h}$ failed to decrease GLI1 expression. (F) Concurrent administration of SAG $(500 \mathrm{nM})$ and SANT1 (dose response) for $48 \mathrm{~h}$ demonstrated that after activation of SMO by SAG, SANT1 inhibited GLI1 expression at 100 and 1,000 $\mathrm{nM}(\mathrm{p}<0.03$, ANOVA). (E and F) Data are the mean and standard error of 3 and 4 experimental replicates, respectively.

respond to modulation of SMO with changes in GLI-MT, we activated and inhibited SMO activity with a small molecule SMO agonist, SAG, and antagonist, SANT1, respectively. We anticipated that GLI-MT would be increased after treatment with SAG and inhibited after treatment with SANT1 in the non-cancer cells with PC. Both NAF and IOSE responded to SAG treatment with an increase in GLI1 mRNA expression. The highly ciliated NAF demonstrated the greatest fold increase in GLI1 with 48- and 72-h treatment with $250 \mathrm{nM}$ SAG (Fig. 2A). A dose response (100-1,000 nM SAG) at $60 \mathrm{~h}$ of treatment indicated the greatest response at $500 \mathrm{nM}$ SAG (Fig. 2B, p=0.01, ANOVA). A similar response to SAG with greatest activation at intermediate doses and less activation at higher doses has been reported previously in other non-cancer cell lines (33). IOSE also showed an increase in GLI1 after treatment with 100-1,000 nM SAG (Fig. 2C, p=0.02, ANOVA; 
A

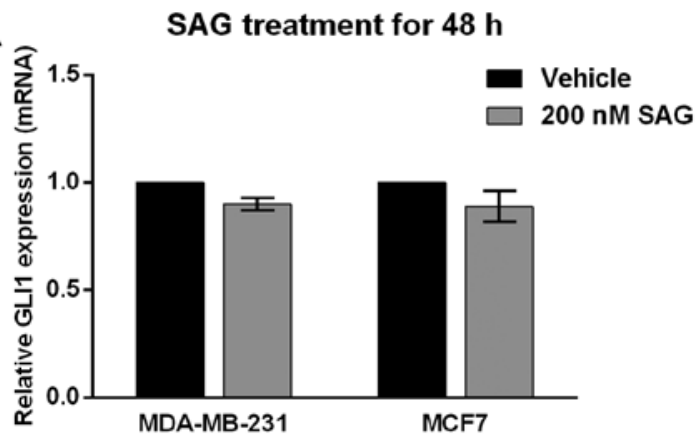

C

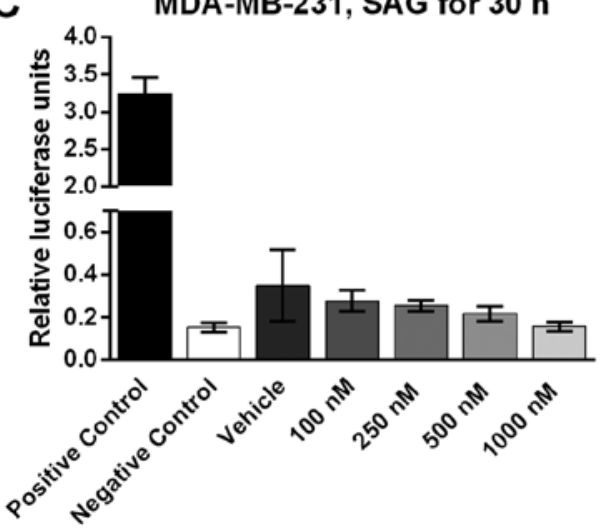

B

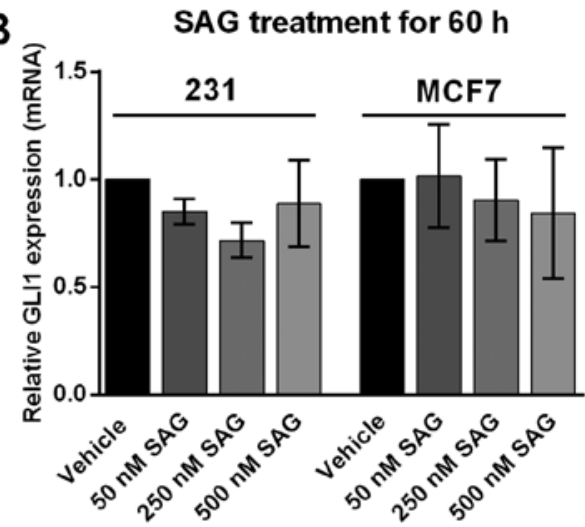

D

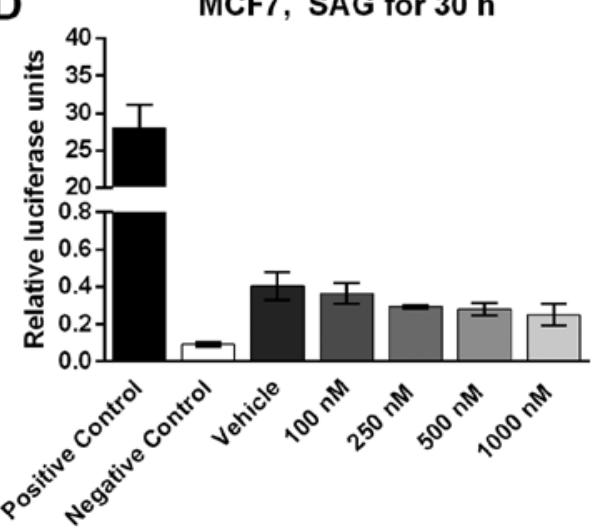

Figure 3. SMO agonist has no effect on GLI-MT in non-ciliated cancer cells. Both GLI1 mRNA expression levels and activity of a GLI-luciferase reporter are unchanged by SAG in non-ciliated cancer cell lines, MCF7 and 231. (A and B) Treatment with $200 \mathrm{nM} \mathrm{SAG}$ for $48 \mathrm{~h}$ and $50-500 \mathrm{nM} \mathrm{SAG}$ for $60 \mathrm{~h}$ did not alter the level of GLI1 mRNA expression. (A) Data are the mean and standard deviation of three assay replicates. (B) Data are the mean and standard error of three experimental replicates. 231 (C) and MCF7 (D) cells were treated with 100-1,000 nM SAG for $30 \mathrm{~h}$ following cotransfection with the pGL3B/8xGliBS-lc-luc vector and the Renilla control vector pRL-TK. Positive control cells were transfected with a GLI1 expression vector and negative control cells with the pGL3-Basic empty vector. There was no increase in luciferase activity. Firefly luciferase activity was normalized to Renilla luciferase activity. Data are the mean and standard error of 4 replicate experiments.

and Fig. 2D, p<0.001, ANOVA), but this increase was less than that seen in NAF, which has a higher incidence of PC. To demonstrate antagonism of SMO activity, IOSE were treated with SANT1. There was no significant response to SANT1 alone, without activation of SMO by co-treatment with SAG (Fig. 2E). Sequential (data not shown) or simultaneous treatment (Fig. 2F, p=0.03, ANOVA) of IOSE with SAG and SANT1 (20-1,000 nM) resulted in a dose-dependent decrease in GLI1. These results confirm that ciliated, non-cancer cells will respond to modulation of SMO with a corresponding modulation in GLI-MT.

Treatment of non-ciliated cancer cells with antagonists and agonists of SMO does not alter GLI-mediated transcription. To determine whether modulation of SMO activity resulted in changes in GLI-MT in non-ciliated cancer cells, we first treated MCF7 and 231 cells with SAG at doses and time-points similar to those that were effective in NAF and IOSE. SAG did not increase GLI1 expression in either cell line (Fig. 3A and B). Because of concern that GLI1 may not be a reliable transcriptional target of GLI-MT in these cells, we transiently transfected a luciferase reporter of GLI transcriptional activity, which we and others have used previously $(33,34)$. Treatment with 100-1,000 nM SAG for $30 \mathrm{~h}$ was begun 2 days after trans- fection. There was no increase in luciferase reporter activity in either cell line, supporting the GLI1 expression data (Fig. 3C and D).

Treatment of these cell lines with SANT1 at doses and time-points similar to those used in the ciliated, non-cancer cells failed to decrease GLI1 expression (Fig. 4A and B) and did not affect cell viability by MTT assay (Fig. 4C). Because SAG did not increase GLI1 expression in these cell lines, concurrent treatment with SAG and SANT1 would not have the same effect as seen in the ciliated non-cancer cells. We and others have reported a decrease in viability in breast cancer cell lines after treatment with another SMO antagonist, cyclopamine. However, cyclopamine has also been shown to have significant off-target effects and to decrease viability independently of SMO inhibition $(35,36)$. To demonstrate that cyclopamine induces cell death independently of hedgehog signaling, we treated 231 cells with a range of concentrations of cyclopamine, including concentrations equal to and higher than those previously utilized for SMO antagonism in mouse fibroblasts (37), and found a dose-dependent decrease in viability without a similar decrease in GLI1 expression (Fig. 4D and E). Furthermore, overexpression of GLI1 in 231 cells failed to rescue the effect of cyclopamine on viability (Fig. 4F). These data indicate that attempts to modulate GLI-MT by targeting 
A

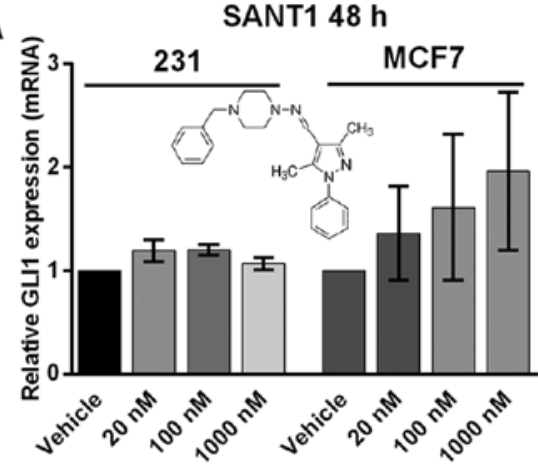

C

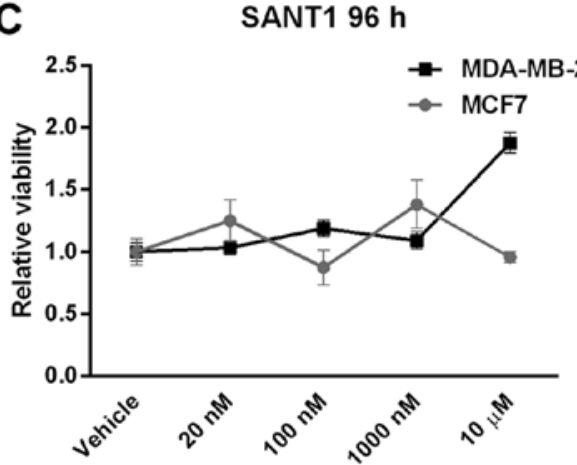

E

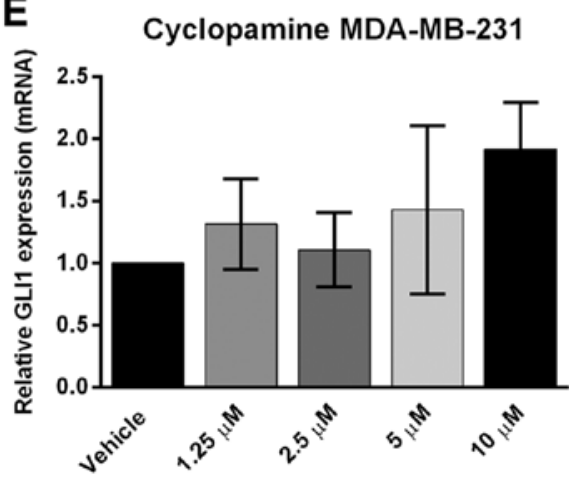

B

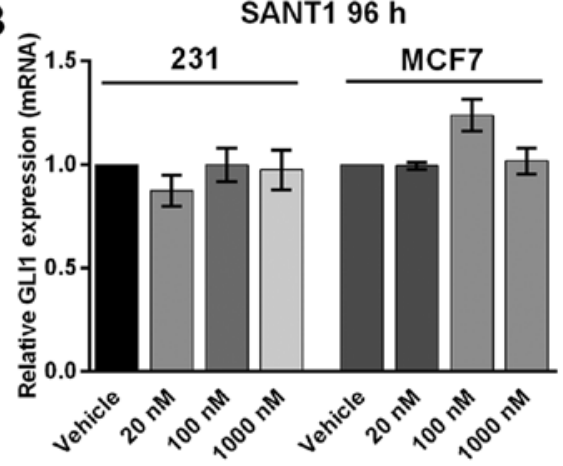

D

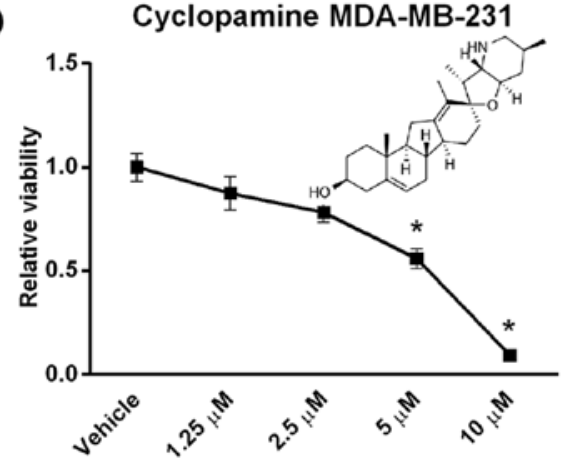

$\mathbf{F}$

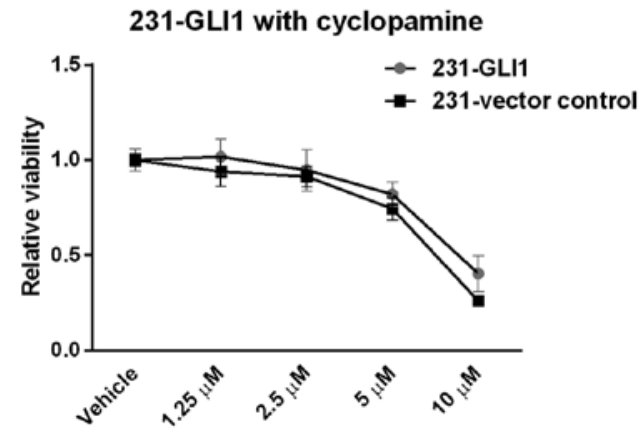

Figure 4. SMO antagonists in non-ciliated cancer cells do not decrease GLI-MT. (A and B) The SMO inhibitor SANT1 was used at a range of concentrations (20-1,000 nM) in 231 and MCF7 for $48 \mathrm{~h}$ (A) and $96 \mathrm{~h}$ (B) with no significant change in relative GLI1 mRNA expression. Data are the mean and standard error of 2-3 independent experiments. The chemical structure for SANT1 is provided (A). (C) Similar treatment with SANT1 for $96 \mathrm{~h}$ did not significantly decrease cell viability as measured by MTT assay. Data are the mean and standard error of 3 independent experiments. (D and E) Treatment of 231 cells with another SMO antagonist, cyclopamine, for $96 \mathrm{~h}$ does affect cell viability significantly ( $\mathrm{p}<0.001$, ANOVA), as measured by MTT assay (D), despite failing to decrease the level of GLI1 mRNA expression after $48 \mathrm{~h}$ (E). (F) 231 cells were transfected with pcDNA3.1-HA-Gli1 to overexpress GLI1 or with the control empty vector. GLI1 mRNA overexpression was confirmed by RT-qPCR and western blot analysis (not shown). Cells were treated with cyclopamine in the concentrations indicated for $96 \mathrm{~h}$ prior to assessment of viability by MTT assay. Overexpression of GLI1 failed to prevent the decrease in viability in 231 cells caused by cyclopamine with a significant decrease in viability at $10 \mu \mathrm{M}$ in both cell lines ( $\mathrm{p}<0.001$ for both, ANOVA). (D-F) The mean and standard error of 3 independent experiments. The chemical structure for cyclopamine is provided (D).

SMO in these specific non-ciliated cancer cell lines are not effective.

Treatment of ciliated cancer cells with a SMO agonist and antagonist fails to modulate GLI-mediated transcription. Because the SKOV3 cells have a relatively high percentage of cells with PC, greater than that found in IOSE, we theorized that they would respond to modulation of SMO activity, as do IOSE. SKOV3 were serum starved for $48 \mathrm{~h}$ prior to treatment to allow formation of PC then treated with $500 \mathrm{nM} \mathrm{SAG}$ for 4-72 h and increasing doses of SAG for $24 \mathrm{~h}$. There was no increase in expression of GLI1 in response to SAG at any time-point or dose (Fig. 5A and B). SKOV3 were also transiently transfected with the luciferase reporter of GLI transcriptional activity and treated with 250 and $500 \mathrm{nM} \mathrm{SAG}$ for $30 \mathrm{~h}$ similarly to the 231 and MCF7 cells, with no increase in reporter activity (Fig. 5C). Because the transfection process disrupts PC, treatment with SAG was also delayed for 3 and 4 days to allow time after transfection for PC to assemble. There was a corresponding increase in PC with time (Fig. 5D). However, there was no 

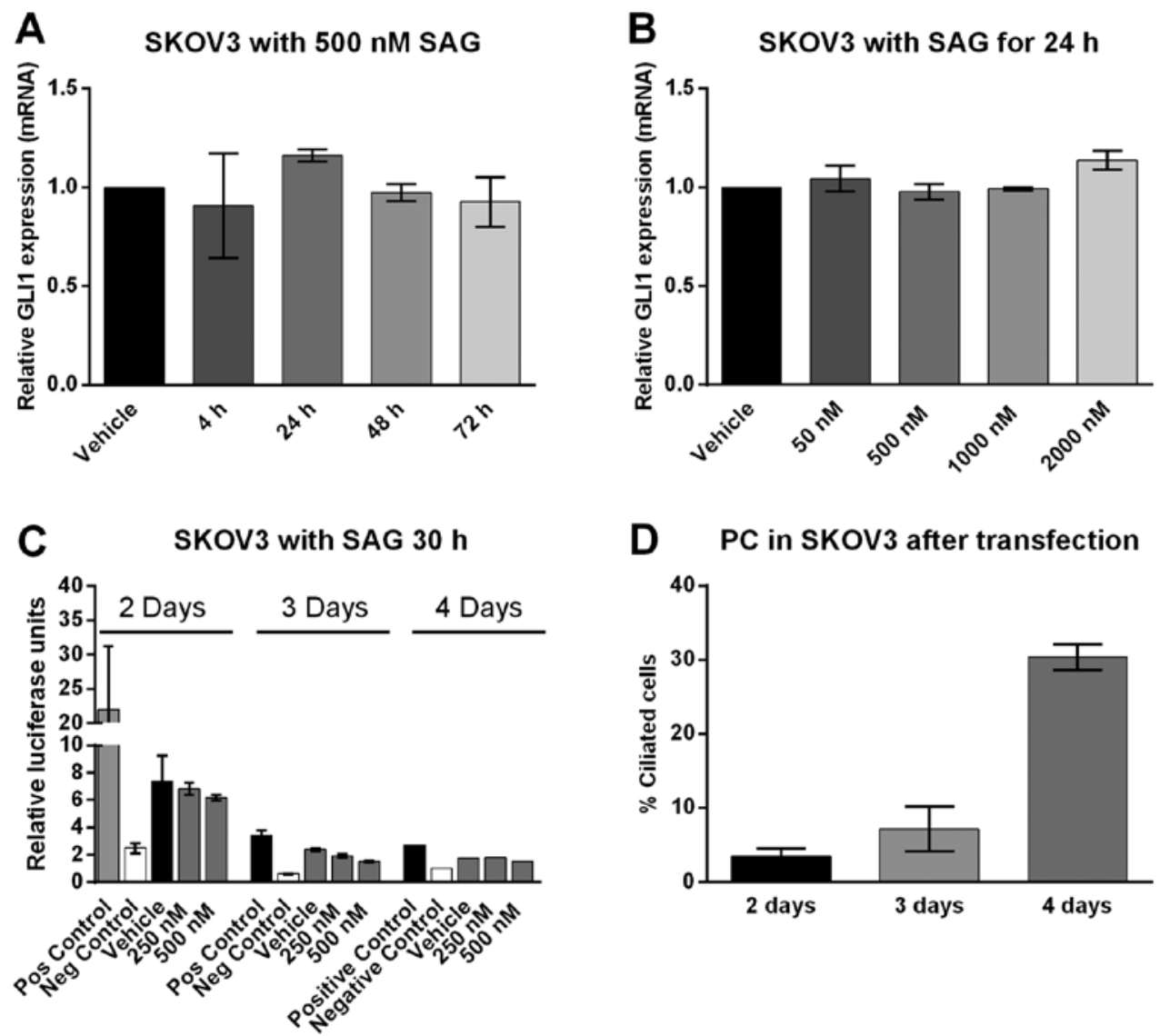

\section{PC in SKOV3 after transfection}
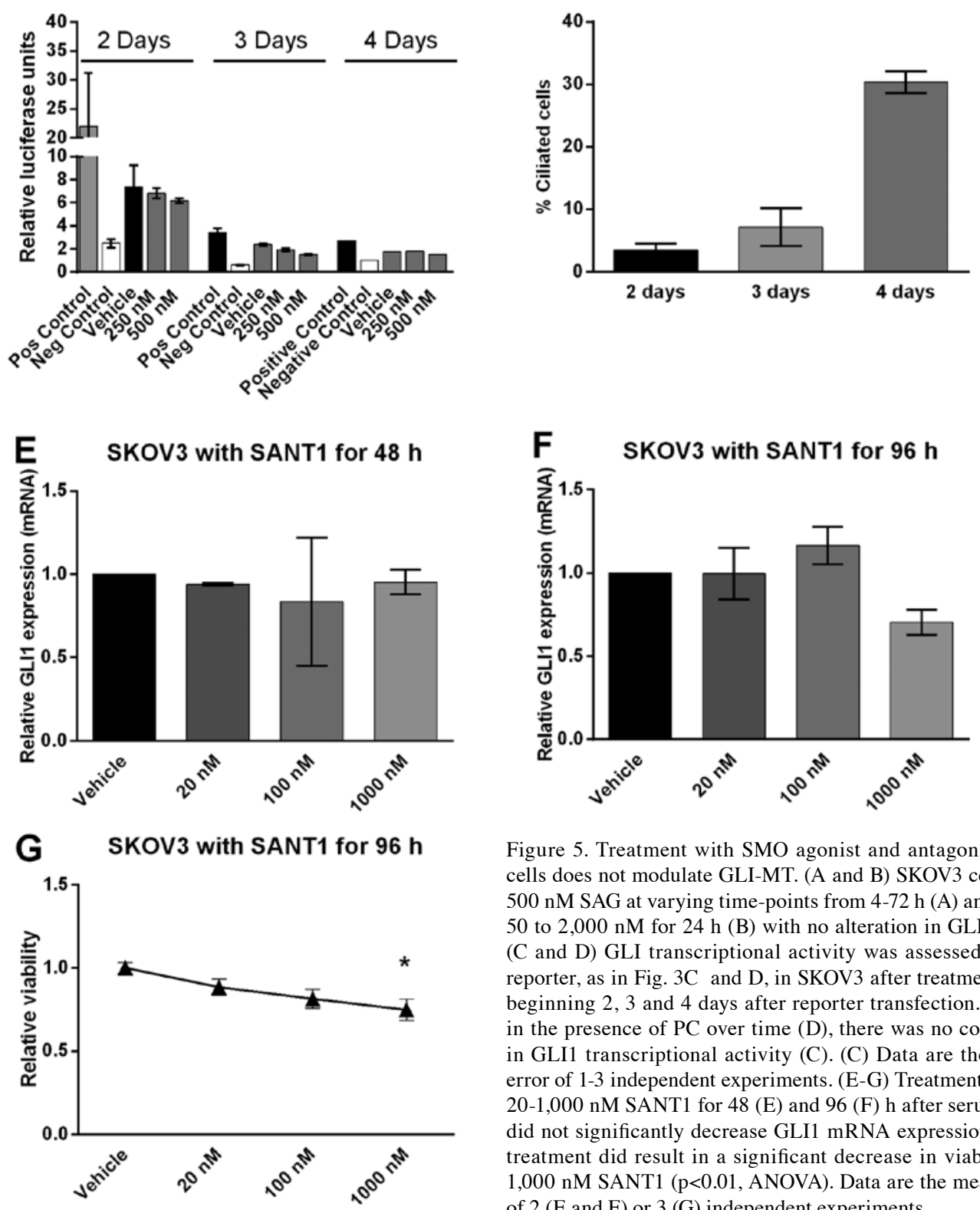

Figure 5. Treatment with SMO agonist and antagonist in ciliated cancer cells does not modulate GLI-MT. (A and B) SKOV3 cells were treated with $500 \mathrm{nM} \mathrm{SAG}$ at varying time-points from $4-72 \mathrm{~h}(\mathrm{~A})$ and doses ranging from 50 to $2,000 \mathrm{nM}$ for $24 \mathrm{~h}$ (B) with no alteration in GLI1 mRNA expression. (C and D) GLI transcriptional activity was assessed by a GLI-luciferase reporter, as in Fig. 3C and D, in SKOV3 after treatment with SAG for $30 \mathrm{~h}$ beginning 2, 3 and 4 days after reporter transfection. Despite the increase in the presence of PC over time (D), there was no corresponding increase in GLI1 transcriptional activity (C). (C) Data are the mean and standard error of 1-3 independent experiments. (E-G) Treatment of SKOV3 cells with 20-1,000 nM SANT1 for 48 (E) and 96 (F) h after serum starvation for $48 \mathrm{~h}$ did not significantly decrease GLI1 mRNA expression. (G) However, 96-h treatment did result in a significant decrease in viability (MTT assay) at $1,000 \mathrm{nM}$ SANT1 ( $<<0.01$, ANOVA). Data are the mean and standard error of $2(\mathrm{E}$ and $\mathrm{F})$ or $3(\mathrm{G})$ independent experiments.

appreciable increase in GLI-mediated transcription with SAG treatment at 3 and 4 days post-transfection, although reporter activity in general is decreased overtime in this assay, limiting interpretation of the results at 4 days.

SKOV3 has a high basal level of GLI1, indicating a high level of GLI-mediated transcription. To determine whether SMO antagonism is effective in reducing GLI-mediated transcription in this ciliated cancer cell line, we treated SKOV3 

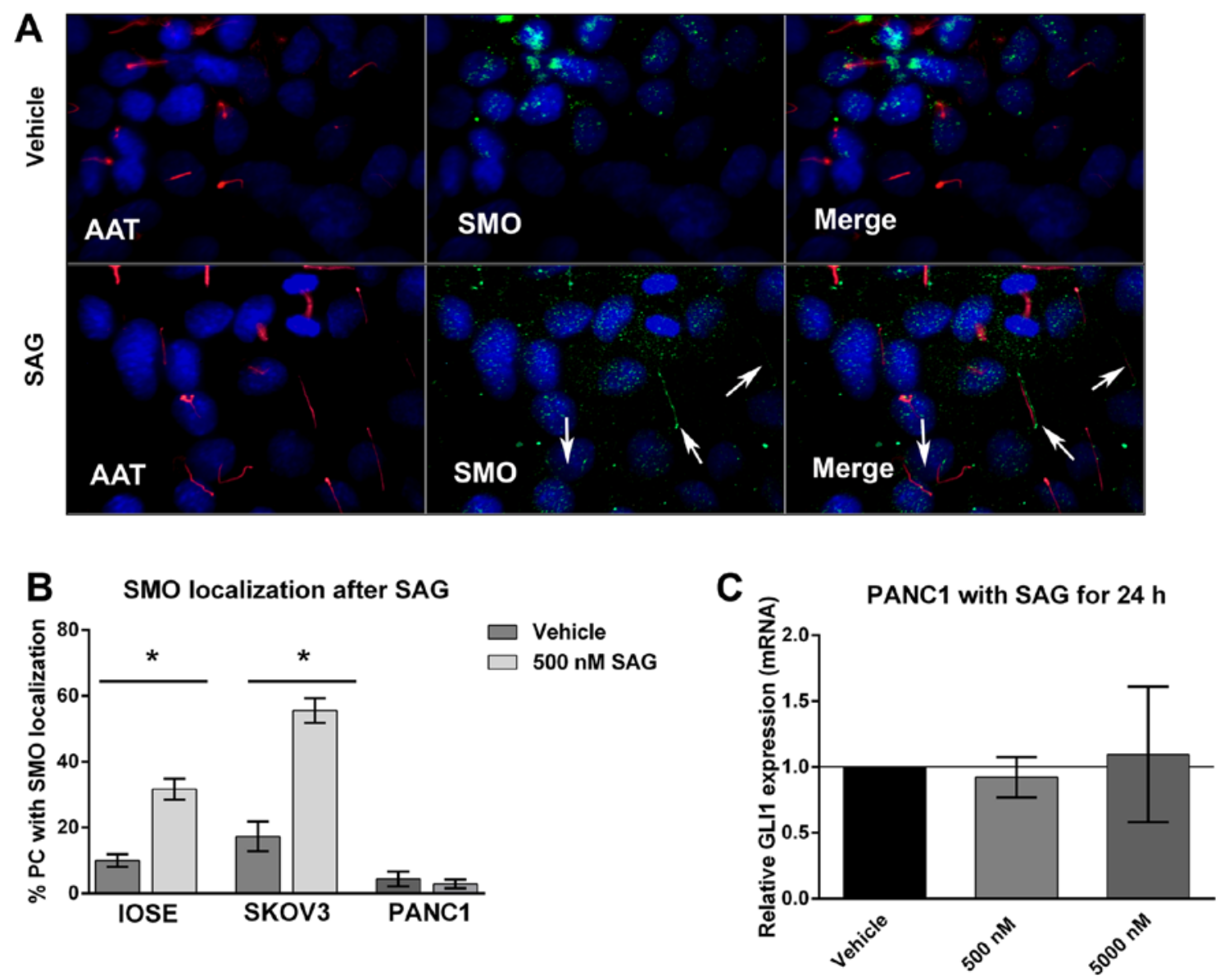

Figure 6. SMO localizes to the PC of ciliated non-cancer and SKOV3 cells in response to a SMO agonist. PC in IOSE, SKOV3 and PANC1 cells were identified by immunofluorescence for acetylated $\alpha$-tubulin (AAT, red), a marker for the ciliary axoneme, and SMO (green) in the presence and absence of $500 \mathrm{nM}$ SAG after serum starvation for $48 \mathrm{~h}$. Nuclei were stained with DAPI (blue). (A) Photomicrographs of the immunofluorescence for AAT and SMO in SKOV3, with and without SAG treatment, are shown. The merged image has a slight shift in the individual component images in order to visualize the SMO and AAT signals immediately adjacent to one another (magnification, x1,000). (B) The percentage of PC with and without SMO location was assessed in a minimum of 100 PC per condition. A significant translocation of SMO to PC was observed after SAG treatment in IOSE and SKOV3 ( $\mathrm{p}=0.03$ and $\mathrm{p}=0.004$, respectively, Mann-Whitney test), but not in PANC1. (C) In PANC1, GLI1 mRNA was assessed by quantitative RT-PCR and there was no increase after SAG treatment. Data are the mean and standard error of 2 independent experiments.

with SANT1 for 48 and $96 \mathrm{~h}$ after serum starvation for $48 \mathrm{~h}$. There was no decrease in GLI1 mRNA at $48 \mathrm{~h}$ and an insignificant decrease at $96 \mathrm{~h}$ at $1,000 \mathrm{nM}$ (Fig. 5E and F). Cell viability was also slightly decreased at $1,000 \mathrm{nM}$ after $96-\mathrm{h}$ treatment, suggesting that the trend to a lower GLI1 at higher concentrations may be a result of decreased viability (Fig. 5G, $\mathrm{p}=0.01$, ANOVA). The absence of any decrease in GLI1 at an earlier time-point also supports a non-specific cytotoxic effect of SANT1 after 96-h treatment. From these data, we conclude that neither SAG nor SANT1 is effective in modulating canonical hedgehog signaling via SMO and affecting GLI-MT in this ciliated cancer cell line.

SAG causes the localization of SMO to PC in both IOSE and SKOV3. Similar to sonic hedgehog ligand, SAG has been shown to induce the translocation of SMO into the PC from other locations in the cell in embryonic mouse fibroblasts and human embryonic stem cells $(31,38,39)$. To confirm that this was also the case in IOSE, IOSE were treated with $500 \mathrm{nM}$ SAG for $24 \mathrm{~h}$ after serum starvation for $48 \mathrm{~h}$. Co-immunofluorescence (IF) staining for acetylated $\alpha$-tubulin (AAT) and SMO was performed and the number of PC with localization of SMO (co-localization of anti-SMO and anti-AAT) and without localization of SMO (marked by anti-AAT only) was assessed (Fig. 6A). The percentage of PC with SMO localization was significantly higher after SAG treatment (Fig. 6B, $p=0.03$, Mann-Whitney test), confirming that in non-cancer ciliated cells, SAG induces the translocation of SMO to the PC. Because of the absence of an increase in GLI-MT after treatment with SAG in SKOV3 cells, we anticipated that there would be no increase in SMO localization to PC after SAG treatment. SKOV3 were treated with SAG, similarly to IOSE, and IF was performed to detect SMO localization in PC. There was no significant difference between the percentage of PC with SMO localization in unstimulated SKOV3 and IOSE (Fig. 6B) despite the higher baseline level of GLI1 expression in SKOV3 (Fig. 1C), again supporting activation of GLI-MT by mechanisms other than hedgehog signaling. Surprisingly, SAG induced an increase in the localization of SMO to the PC in SKOV3 (Fig. 6B, p=0.004, Mann-Whitney test). Therefore, SAG induced the translocation of SMO into the PC, but subsequent activation of GLI-MT did not occur. This suggests a defect in transmission of the hedgehog signal after localization of SMO to the PC in SKOV3 cells. To determine whether 
SMO localization to PC without downstream activation of GLI-mediated transcription is typical of ciliated cancer cell lines, we similarly treated another cancer cell line, PANC1, a ciliated pancreatic cancer cell line, with SAG and assessed GLI1 expression and localization of SMO to PC (Fig. 6B and C). After 48-h serum starvation, $15-20 \%$ of PANC1 have PC. Similar to SKOV3, there was no increase in GLI1 mRNA in PANC1 after SAG treatment (Fig. 6C). However, unlike SKOV3 there was no significant increase in localization of SMO to PC (Fig. 6B).

\section{Discussion}

Data to date indicate that, in general, $\mathrm{PC}$ are lost during carcinogenesis. Only a few different types of cancer have been assessed for the presence of PC and typically the number of cancers examined in these studies is relatively small $(20,22)$. A single report of 8 human BCC showed that $60 \%$ were highly ciliated, similar to normal keratinocytes, whereas $40 \%$ did not contain ciliated cells (40). In most invasive breast carcinomas, $\mathrm{PC}$ are absent or present at a very low frequency in the cancer epithelial cells $(22,28,29)$. Similarly in prostate cancer, more than $95 \%$ of cancers have no or infrequent cancer epithelial cells with PC (41). In pancreatic cancer, only $25 \%$ of invasive cancers exhibited PC in cancer epithelial cells (42). These findings suggest that BCC (60\% with PC) are more highly ciliated than some other solid carcinomas (0-25\% with PC).

Several hundreds of compounds have been reported to inhibit HH signaling. Only 8 of these compounds have entered clinical trials and all of these are antagonists of SMO (2). These SMO antagonists have been tested in phase I/II clinical trials for their efficacy in advanced stage solid tumors and leukemia. The best results have been seen in basal cell carcinomas and with the SMO antagonist, vismodegib (also known as GDC-0449), which has been approved by the United States Food and Drug Administration for the treatment of locally advanced or metastatic basal cell carcinoma (BCC) of the skin (2). The results of clinical trials of SMO antagonists in advanced stage solid cancers other than BCC have not shown a significant clinical response $(43,44)$. Furthermore, even in BCC, only about half of patients treated with vismodegib had a clinical response $(43,45,46)$. The facts that: i) the cells of BCC are more likely to be ciliated than other solid cancers; and ii) $\mathrm{BCC}$ are more responsive to SMO antagonism than other cancers raises the possibility that the presence of $\mathrm{PC}$ in cancer cells might predict responsiveness to SMO antagonism.

In the present study, we addressed whether the presence of PC in cancer epithelial cells indicates active autocrine canonical hedgehog signaling and responsiveness to modulation of SMO activity with a corresponding change in GLI-MT. We showed that the presence of PC in the cancer cells tested does not assure that modulation of SMO will affect GLI-MT in these cells. In the ciliated SKOV3 ovarian cancer cells, treatment with SAG failed to increase GLI-MT, but resulted in the translocation of SMO into the PC. It is believed that SMO exists in three activity states: i) inactive cytoplasmic; ii) inactive ciliary; and iii) active ciliary, and that activation of SMO is a two-step process. The first step is translocation to the PC (transition from inactive cytoplasmic to inactive ciliary) and the second step is activation of SMO (transition from inactive ciliary to active ciliary) (47). The ciliary localization in the absence of induced GLI-MT, suggests that SMO is in the inactive ciliary state after SAG treatment of SKOV3, and that the transition from the inactive to active ciliary state is blocked in SKOV3 or that activated ciliary SMO is incapable of initiating the processing of GLI2 and GLI3 to their activator forms to initiate GLI-MT. The activation of GLI2 and GLI3 in the PC is complicated and not entirely defined, but includes the interactions of multiple other hedgehog pathway components, including suppressor of fused, Kif7, protein kinase A, EVC, EVC2, and integrin-linked kinase $(8,48)$. Therefore, a defect in the presence or activity of any of these molecules might explain the absence of a downstream response to SMO agonism. Treatment of another ciliated cancer cell line, PANC1 pancreatic cancer cells, with SAG did not induce localization of SMO to PC. This is similar to a prior report, in which there was no localization of SMO to PC after SAG treatment in another pancreatic cancer cell line, CFPAC1 (31), suggesting that transmission of the hedgehog signal is also defective in other ciliated cancers and, furthermore, the molecular mechanism responsible for the defect likely varies in different cancers.

Even though our data show that the presence of PC in cancer epithelial cells will not ensure that these cells respond to SMO antagonists with a decrease in GLI-MT, they do not eliminate the possibility that the stromal cells in carcinomas will respond to SMO antagonism. In animal models of pancreatic cancer, canonical hedgehog signaling has been shown to be restricted to stromal cells (49), suggesting the possibility that inhibition of stromal hedgehog signaling by SMO antagonists may be therapeutically efficacious $(50,51)$. However, the results of clinical trials of SMO antagonists in pancreatic cancer have not shown a therapeutic benefit $(52,53)$ and recent pre-clinical data suggest that inhibition of SMO in the stroma in pancreatic cancer actually promotes cancer progression (53).

Our data also suggest that many cancer cells, either with or without PC, will not respond to SMO antagonists with a decrease in GLI-MT. However, GLI-MT has been shown to be increased in many cancer types. In BCC, activation of canonical hedgehog signaling, usually a result of genetic mutation of pathway members, is critical for tumorigenesis and cancer maintenance (54). The importance of canonical hedgehog signaling in other cancer types, in which activating mutations are very rare, is less well-established than in BCC. Much of the laboratory data demonstrating a response to SMO antagonism in these cancers was generated using the SMO antagonist cyclopamine at high concentrations. Cyclopamine is now known to result in significant off-target effects $(35,36,44)$, which we confirmed here (Fig. 4). Yet, modulation of GLI-MT by direct expression or silencing of the GLI transcription factors has demonstrated a promotional role for GLI transcriptional activity in the development and progression of diverse types of solid cancers $(5,10,17)$. Our data suggest that in at least some cancers, activation of GLI-MT is not via canonical hedgehog signaling through SMO, but is a result of activation of other signaling pathway(s), such as ras or TGF $\beta$. Therefore, a different therapeutic strategy is to target GLI-MT in cancer cells at the level of the GLI transcription factors. Several such antagonists of GLI-MT have been identified and are being developed for human use $(55,56)$. 
In conclusion, we showed that the presence or absence of $\mathrm{PC}$ in several breast, ovarian and pancreatic cancer cell lines cannot be used to predict the ability of agonists or antagonists of SMO to increase or decrease, respectively, GLI-MT in these cells. While this is only a small selection of cell lines, the results suggest that the presence of primary cilia in cancer epithelial cells will not be an effective biomarker to indicate responsiveness to SMO antagonists clinically. Additionally, we demonstrate defective canonical hedgehog signaling in each of the cancer cell lines tested and provide data suggesting that the mechanisms underlying the inability of SMO to activate hedgehog signaling varies in different cancers. The lack of modulation of GLI-MT by a SMO agonist and antagonist in these cancer cell lines also support the clinical trial data demonstrating a lack of a significant clinical response in most solid cancers.

\section{Acknowledgements}

This study was supported by Susan G. Komen for the Cure (KG110409, BCTR0707453) and the United States Department of Defense Breast Cancer Research Program (BC083907).

\section{References}

1. Brechbiel J, Miller-Moslin K and Adjei AA: Crosstalk between hedgehog and other signaling pathways as a basis for combination therapies in cancer. Cancer Treat Rev 40: 750-759, 2014.

2. Xie J, Bartels CM, Barton SW and Gu D: Targeting hedgehog signaling in cancer: Research and clinical developments. Onco Targets Ther 6: 1425-1435, 2013.

3. Shen F, Cheng L, Douglas AE, Riobo NA and Manning DR: Smoothened is a fully competent activator of the heterotrimeric G protein G(i). Mol Pharmacol 83: 691-697, 2013.

4. Fernández-Zapico ME: Primers on molecular pathways GLI More than just Hedgehog? Pancreatology 8: 227-229, 2008

5. Stecca B and Ruiz I Altaba A: Context-dependent regulation of the GLI code in cancer by HEDGEHOG and non-HEDGEHOG signals. J Mol Cell Biol 2: 84-95, 2010.

6. Kasper M, Regl G, Frischauf AM and Aberger F: GLI transcription factors: Mediators of oncogenic Hedgehog signalling. Eur J Cancer 42: 437-445, 2006.

7. Lipinski RJ, Gipp JJ, Zhang J, Doles JD and Bushman W: Unique and complimentary activities of the Gli transcription factors in Hedgehog signaling. Exp Cell Res 312: 1925-1938, 2006.

8. Nozawa YI, Lin C and Chuang PT: Hedgehog signaling from the primary cilium to the nucleus: An emerging picture of ciliary localization, trafficking and transduction. Curr Opin Genet Dev 23: 429-437, 2013.

9. Briscoe $\mathrm{J}$ and Thérond PP: The mechanisms of Hedgehog signalling and its roles in development and disease. Nat Rev Mol Cell Biol 14: 416-429, 2013.

10. Hui CC and Angers S: Gli proteins in development and disease. Annu Rev Cell Dev Biol 27: 513-537, 2011.

11. Dennler S, André J, Alexaki I, Li A, Magnaldo T, ten Dijke P, Wang XJ, Verrecchia F and Mauviel A: Induction of sonic hedgehog mediators by transforming growth factor-beta: Smad3-dependent activation of Gli2 and Gli1 expression in vitro and in vivo. Cancer Res 67: 6981-6986, 2007.

12. Ji Z, Mei FC, Xie J and Cheng X: Oncogenic KRAS activates hedgehog signaling pathway in pancreatic cancer cells. J Biol Chem 282: 14048-14055, 2007.

13. Stecca B, Mas C, Clement V, Zbinden M, Correa R, Piguet V, Beermann $\mathrm{F}$ and Ruiz I Altaba A: Melanomas require HEDGEHOG-GLI signaling regulated by interactions between GLI1 and the RAS-MEK/AKT pathways. Proc Natl Acad Sci USA 104: 5895-5900, 2007.

14. Noubissi FK, Goswami S, Sanek NA, Kawakami K, Minamoto T, Moser A, Grinblat Y and Spiegelman VS: Wnt signaling stimulates transcriptional outcome of the Hedgehog pathway by stabilizing GLI1 mRNA. Cancer Res 69: 8572-8578, 2009.
15. Yoon JW, Gallant M, Lamm ML, Iannaccone S, Vieux KF, Proytcheva M, Hyjek E, Iannaccone P and Walterhouse D: Noncanonical regulation of the Hedgehog mediator GLI1 by c-MYC in Burkitt lymphoma. Mol Cancer Res 11: 604-615, 2013.

16. Pasca di Magliano $M$ and Hebrok M: Hedgehog signalling in cancer formation and maintenance. Nat Rev Cancer 3: 903-911, 2003.

17. Kwon YJ, Hurst DR, Steg AD, Yuan K, Vaidya KS, Welch DR and Frost AR: Gli1 enhances migration and invasion via up-regulation of MMP-11 and promotes metastasis in ER $\alpha$ negative breast cancer cell lines. Clin Exp Metastasis 28: 437-449, 2011.

18. Abidi A: Hedgehog signaling pathway: a novel target for cancer therapy: vismodegib, a promising therapeutic option in treatment of basal cell carcinomas. Indian J Pharmacol 46: 3-12, 2014.

19. Sekulic A, Migden MR, Oro AE, Dirix L, Lewis KD, Hainsworth JD, Solomon JA, Yoo S, Arron ST, Friedlander PA, et al: Efficacy and safety of vismodegib in advanced basal-cell carcinoma. N Engl J Med 366: 2171-2179, 2012.

20. Hassounah NB, Bunch TA and McDermott KM: Molecular pathways: The role of primary cilia in cancer progression and therapeutics with a focus on Hedgehog signaling. Clin Cancer Res 18: 2429-2435, 2012.

21. Han YG, Kim HJ, Dlugosz AA, Ellison DW, Gilbertson RJ and Alvarez-Buylla A: Dual and opposing roles of primary cilia in medulloblastoma development. Nat Med 15: 1062-1065, 2009.

22. Yuan K, Serra R and Frost AR: Primary cilia in the breast and breast cancer. Open Breast Cancer J 2: 101-107, 2010.

23. Sadlonova A, Novak Z, Johnson MR, Bowe DB, Gault SR, Page GP, Thottassery JV, Welch DR and Frost AR: Breast fibroblasts modulate epithelial cell proliferation in three-dimensional in vitro co-culture. Breast Cancer Res 7: R46-R59, 2005.

24. Steg A, Wang W, Blanquicett C, Grunda JM, Eltoum IA, Wang K, Buchsbaum DJ, Vickers SM, Russo S, Diasio RB, et al: Multiple gene expression analyses in paraffin-embedded tissues by TaqMan low-density array: Application to hedgehog and Wnt pathway analysis in ovarian endometrioid adenocarcinoma. J Mol Diagn 8: 76-83, 2006.

25. Berbari NF, O'Connor AK, Haycraft CJ and Yoder BK: The primary cilium as a complex signaling center. Curr Biol 19: R526-R535, 2009.

26. Yuan K, Frolova N, Xie Y, Wang D, Cook L, Kwon YJ, Steg AD, Serra R and Frost AR: Primary cilia are decreased in breast cancer: Analysis of a collection of human breast cancer cell lines and tissues. J Histochem Cytochem 58: 857-870, 2010.

27. Egeberg DL, Lethan M, Manguso R, Schneider L, Awan A, Jørgensen TS, Byskov AG, Pedersen LB and Christensen ST: Primary cilia and aberrant cell signaling in epithelial ovarian cancer. Cilia 1: 15, 2012.

28. Menzl I, Lebeau L, Pandey R, Hassounah NB, Li FW, Nagle R, Weihs K and McDermott KM: Loss of primary cilia occurs early in breast cancer development. Cilia 3: 7, 2014.

29. Nobutani K, Shimono Y, Yoshida M, Mizutani K, Minami A, Kono S, Mukohara T, Yamasaki T, Itoh T, Takao S, et al: Absence of primary cilia in cell cycle-arrested human breast cancer cells. Genes Cells 19: 141-152, 2014.

30. Kruk PA and Auersperg N: Human ovarian surface epithelial cells are capable of physically restructuring extracellular matrix. Am J Obstet Gynecol 167: 1437-1443, 1992.

31. Nielsen SK, Møllgård K, Clement CA, Veland IR, Awan A, Yoder BK, Novak I and Christensen ST: Characterization of primary cilia and Hedgehog signaling during development of the human pancreas and in human pancreatic duct cancer cell lines. Dev Dyn 237: 2039-2052, 2008.

32. Lewis MT and Veltmaat JM: Next stop, the twilight zone: Hedgehog network regulation of mammary gland development. J Mammary Gland Biol Neoplasia 9: 165-181, 2004.

33. Chen JK, Taipale J, Young KE, Maiti T and Beachy PA: Small molecule modulation of Smoothened activity. Proc Natl Acad Sci USA 99: 14071-14076, 2002.

34. Mukherjee S, Frolova N, Sadlonova A, Novak Z, Steg A, Page GP, Welch DR, Lobo-Ruppert SM, Ruppert JM, Johnson MR, et al: Hedgehog signaling and response to cyclopamine differ in epithelial and stromal cells in benign breast and breast cancer. Cancer Biol Ther 5: 674-683, 2006.

35. Zhang X, Harrington N, Moraes RC, Wu MF, Hilsenbeck SG and Lewis MT: Cyclopamine inhibition of human breast cancer cell growth independent of Smoothened (Smo). Breast Cancer Res Treat 115: 505-521, 2009. 
36. Meyers-Needham M, Lewis JA, Gencer S, Sentelle RD, Saddoughi SA, Clarke CJ, Hannun YA, Norell H, da Palma TM, Nishimura M, et al: Off-target function of the Sonic hedgehog inhibitor cyclopamine in mediating apoptosis via nitric oxidedependent neutral sphingomyelinase $2 /$ ceramide induction. Mol Cancer Ther 11: 1092-1102, 2012.

37. Taipale J, Chen JK, Cooper MK, Wang B, Mann RK, Milenkovic L, Scott MP and Beachy PA: Effects of oncogenic mutations in Smoothened and Patched can be reversed by cyclopamine. Nature 406: 1005-1009, 2000.

38. Wang Y, Arvanites AC, Davidow L, Blanchard J, Lam K, Yoo JW, Coy S, Rubin LL and McMahon AP: Selective identification of hedgehog pathway antagonists by direct analysis of smoothened ciliary translocation. ACS Chem Biol 7: 1040-1048, 2012.

39. Kiprilov EN, Awan A, Desprat R, Velho M, Clement CA, Byskov AG, Andersen CY, Satir P, Bouhassira EE, Christensen ST, et al: Human embryonic stem cells in culture possess primary cilia with hedgehog signaling machinery. J Cell Biol 180: 897-904, 2008.

40. Wong SY, Seol AD, So PL, Ermilov AN, Bichakjian CK, Epstein EH Jr, Dlugosz AA and Reiter JF: Primary cilia can both mediate and suppress Hedgehog pathway-dependent tumorigenesis. Nat Med 15: 1055-1061, 2009.

41. Hassounah NB, Nagle R, Saboda K, Roe DJ, Dalkin BL and McDermott KM: Primary cilia are lost in preinvasive and invasive prostate cancer. PLoS One 8: e68521, 2013.

42. Emoto K, Masugi Y, Yamazaki K, Effendi K, Tsujikawa H, Tanabe M, Kitagawa Y and Sakamoto M: Presence of primary cilia in cancer cells correlates with prognosis of pancreatic ductal adenocarcinoma. Hum Pathol 45: 817-825, 2014.

43. LoRusso PM, Rudin CM, Reddy JC, Tibes R, Weiss GJ, Borad MJ, Hann CL, Brahmer JR, Chang I, Darbonne WC, et al: Phase I trial of hedgehog pathway inhibitor vismodegib (GDC-0449) in patients with refractory, locally advanced or metastatic solid tumors. Clin Cancer Res 17: 2502-2511, 2011.

44. Amakye D, Jagani Z and Dorsch M: Unraveling the therapeutic potential of the Hedgehog pathway in cancer. Nat Med 19: $1410-1422,2013$

45. Tang JY, Mackay-Wiggan JM, Aszterbaum M, Yauch RL, Lindgren J, Chang K, Coppola C, Chanana AM, Marji J, Bickers DR, et al: Inhibiting the hedgehog pathway in patients with the basal-cell nevus syndrome. N Engl J Med 366: $2180-2188,2012$
46. Von Hoff DD, LoRusso PM, Rudin CM, Reddy JC, Yauch RL, Tibes R, Weiss GJ, Borad MJ, Hann CL, Brahmer JR, et al: Inhibition of the hedgehog pathway in advanced basal-cell carcinoma. N Engl J Med 361: 1164-1172, 2009.

47. Wang Y, Zhou Z, Walsh CT and McMahon AP: Selective translocation of intracellular Smoothened to the primary cilium in response to Hedgehog pathway modulation. Proc Natl Acad Sci USA 106: 2623-2628, 2009

48. Barakat B, Yu L, Lo C, Vu D, De Luca E, Cain JE, Martelotto LG, Dedhar S, Sadler AJ, Wang D, et al: Interaction of smoothened with integrin-linked kinase in primary cilia mediates Hedgehog signalling. EMBO Rep 14: 837-844, 2013.

49. Tian H, Callahan CA, DuPree KJ, Darbonne WC, Ahn CP, Scales SJ and de Sauvage FJ: Hedgehog signaling is restricted to the stromal compartment during pancreatic carcinogenesis. Proc Natl Acad Sci USA 106: 4254-4259, 2009.

50. Yauch RL, Gould SE, Scales SJ, Tang T, Tian H, Ahn CP, Marshall D, Fu L, Januario T, Kallop D, et al: A paracrine requirement for hedgehog signalling in cancer. Nature 455: 406-410, 2008

51. Feldmann G, Habbe N, Dhara S, Bisht S, Alvarez H, Fendrich V, Beaty R, Mullendore M, Karikari C, Bardeesy N, et al: Hedgehog inhibition prolongs survival in a genetically engineered mouse model of pancreatic cancer. Gut 57: 1420-1430, 2008.

52. Banerjee U and Hadden MK: Recent advances in the design of Hedgehog pathway inhibitors for the treatment of malignancies. Expert Opin Drug Discov 9: 751-771, 2014.

53. Lee JJ, Perera RM, Wang H, Wu DC, Liu XS, Han S, Fitamant J, Jones PD, Ghanta KS, Kawano S, et al: Stromal response to Hedgehog signaling restrains pancreatic cancer progression. Proc Natl Acad Sci USA 111: E3091-E3100, 2014.

54. Epstein EH: Basal cell carcinomas: Attack of the hedgehog. Nat Rev Cancer 8: 743-754, 2008.

55. Chenna V, Hu C, Pramanik D, Aftab BT, Karikari C, Campbell NR, Hong SM, Zhao M, Rudek MA, Khan SR, et al: A polymeric nanoparticle encapsulated small-molecule inhibitor of Hedgehog signaling (NanoHHI) bypasses secondary mutational resistance to Smoothened antagonists. Mol Cancer Ther 11: 165-173, 2012.

56. Lauth M, Bergström A, Shimokawa T and Toftgård R: Inhibition of GLI-mediated transcription and tumor cell growth by smallmolecule antagonists. Proc Natl Acad Sci USA 104: 8455-8460, 2007. 